\title{
Deeds and Words in the Suffrage Military Hospital in Endell Street
}

\author{
JENNIAN F GEDDES*
}

\section{Introduction}

Shortly after war broke out in 1914 Dr Flora Murray and Dr Louisa Garrett Anderson, two former members of the Women's Social and Political Union, founded their own women's hospital organization to care for soldiers wounded in the fighting. Experience in the suffrage movement had taught them what the likely reaction of the authorities would be to any offer of help from women doctors, so they applied directly to the French, who accepted their offer and assigned them a newly built hotel in Paris for their hospital. During the autumn and early winter of 1914 Murray and Anderson's "Women's Hospital Corps" successfully ran two military hospitals, in Paris and at Wimereux on the Channel coast, until January 1915, when casualties began to be evacuated to England in preference to being treated in France. In the interim, the War Office had received many favourable reports of the WHC's achievements, with the result that at the beginning of 1915 the women were invited to return to England, and given the opportunity to run a large military hospital in the centre of London, under the Royal Army Medical Corps. This hospital, the Endell Street Military Hospital, was open from May 1915 to the end of 1919. Entirely staffed by women, and the only women's unit run by militant suffragists, it was one of the most remarkable hospitals of the war. ${ }^{1}$

By any standards, the achievements of the WHC were astonishing. Their three hospitals were not only administered and staffed by women, but were founded specifically to treat male patients, of whom they had very little experience. The medicine and surgery of the First World War bore no resemblance to the civilian medicine that these women had trained for and practised up until 1914: clinical experience in women's hospitals could not have prepared them to deal with convoys of large numbers of severely injured men, many

(C) Jennian F Geddes 2007

*Dr Jennian F Geddes FRCPath, MA, e-mail: jfgeddes@doctors.org.uk

I should like to thank Katharina Rowold for much constructive criticism; the Anderson family for the loan of archival material; Dick Shaw, Chris Martin, John Wells, Robin Byatt and Cath James for information about their mothers; Victoria North and Victoria Rea, archivists at the Royal Free Archive Centre; Neil McIntyre for information about the history of the LSMW.

Abbreviations: IWM: Imperial War Museum; LGA: Louisa Garrett Anderson; LSMW: London School of Medicine for Women; NUWSS: National Union of Women's Suffrage Societies; RAMC: Royal Army Medical Corps; SWH: Scottish Women's Hospitals;
WAAC: Women's Army Auxiliary Corps; WHC: Women's Hospital Corps; WSPU: Women's Social and Political Union.

\footnotetext{
${ }^{1}$ Accounts can be found in Flora Murray, Women as army surgeons. Being the history of the Women's Hospital Corps in Paris, Wimereux and Endell Street, September 1914-October 1919, London, Hodder and Stoughton, 1920; Jennian F Geddes, 'The Women's Hospital Corps: forgotten surgeons of the First World War', J. med. Biog., 2006, 14: 109-17; Jennian F Geddes, 'Artistic integrity and feminist spin: a spat at the Endell Street Military Hospital', Burlington Magazine, 2005, 147: 617-18; Jennian F Geddes, " "Women as army surgeons": the Women's Hospital Corps', MA thesis, London Metropolitan University, 2005 (held at the Women's Library, London).
} 


\section{Jennian F Geddes}

requiring immediate surgery. Not content with coping with great clinical challenges, however, the Endell Street doctors entered the sphere of academic medicine and were among the first British women doctors to carry out systematic clinical and laboratory research, and to publish it in the scientific press.

Endell Street differed from other women's hospitals of the First World War in that the staff made no secret of their militant views, and the public perceived it to be a specifically suffrage hospital. In forming the group, Murray and Anderson had left no ambiguity about their aims, and, explicitly linking their work with their political aspirations, committed themselves to educating and training the women under their command in their expectations and obligations as future citizens. Ironically, despite the overt feminism of the WHC, there is no doubt that by the end of the war the success of its hospital had played a considerable role in expunging the stigma of the militant years in the eyes of the public at large.

The story of the WHC throws new light on women doctors' war hospitals, in particular the extent to which pre-war involvement in the women's movement influenced the staff who served in them. Accounts of the various hospitals are readily available, ${ }^{2}$ but the latter appears to be a surprisingly under-investigated field. Little is known about the contribution made by professional women, particularly doctors, to the women's movement-and, more interestingly, how active involvement in that movement may have influenced the work they subsequently did during the war. Many of the women doctors who volunteered their services in 1914 had been active suffragists, and WSPU annual reports reveal that Flora Murray and Louisa Garrett Anderson were far from being the only medical supporters of the militant wing. For women who had taken an active part in the suffrage struggle, the participation of medical women in the war effort would be the most potent form of suffrage propaganda, by demonstrating that women were capable both of fulfilling their obligations as citizens and of doing a professional job as well as a man. The evidence is that this was in fact the overriding aim of Murray and Anderson in forming the WHC. That this aspect of women doctors' war work has not so far been addressed may be largely due to the fact that the biggest women's organization, the Scottish Women's Hospitals, tended to play down its suffrage connections in order not to antagonize potential donors, with the result that the political dimension of the women's military hospitals has been overlooked.

Susan Kent's analysis of the experience of women, including doctors, working near the front line during the First War shows that such women acquired an understanding of men's experiences and of men that was much more akin to those of the men themselves. ${ }^{3} \mathrm{Kent}$ suggests that "comfort, caring and giving" rather than "conflict, violence and destruction", characterized the relations between the men and women who had shared experiences of the horrors of war. ${ }^{4}$ Her conclusions have direct relevance to the work of the WHC at Endell Street, because the hospital was known for its highly distinctive nurturing care. An important side effect of their anomalous position as a women's unit in the army was that the

\footnotetext{
${ }^{2}$ Beatrice Harraden, 'Women doctors in the war', Windsor Magazine, 1915, 43: 179-93; Ann M Mitchell, 'Medical women and the medical services of the First World War', in Festschrift for Kenneth Fitzpatrick Russell, Victoria, Queensbury Hill Press, 1978; Leah Leneman, 'Medical women at war, 1914-1918', Med. Hist., 1994, 38: 160-77; I R Whitehead, Doctors in the
}

Great War, London, Leo Cooper, 1999, ch. 5, 'Medical women and war service'.

${ }^{3}$ Susan Kingsley Kent, Making peace: the reconstruction of gender in interwar Britain, Princeton University Press, 1993, ch. 3.

${ }^{4}$ Ibid., p. 73. 


\section{The Suffrage Military Hospital in Endell Street}

Endell Street staff were largely left to their own devices, and were able to do what they wanted. At the same time, being financially supported by the RAMC, they were relieved of the burden of fund-raising that faced any voluntary unit. As a result, they had the opportunity of being able to bring an additional dimension to the care of the sick, concentrating on the psychological as well as the physical needs of their patients - something that was not an option in other military hospitals, especially the field hospitals units run by other women.

\section{Suffragists in Medicine}

In the years preceding the outbreak of the First World War the British political and social scene had been dominated by the campaign of the militant suffragists, principally under the direction of the WSPU. The involvement of women doctors in the suffrage movement has not been studied, but it is known that a majority of the women on the medical register in 1908 were supporters of the cause. ${ }^{5}$ Any glance through annual reports of the various suffrage societies reveals doctors among the contributors, especially to societies that would have particular relevance to professional women, such as the Women's Tax Resistance League. It is likely that there were many supporters of the suffrage movement among medical students too, particularly at the London School of Medicine for Women, for even though the students had no Suffrage Society until 1914, they were encouraged to support the movement. ${ }^{6}$ There was undoubtedly a strong feminist ethos at the School: after lunching at the LSMW in June 1917, Vera Scantlebury, an Australian doctor working at Endell Street, wrote: "the anti-man feeling seemed very strong. The young girls come straight from school and are plunged into this atmosphere-there is not much hope for them!" ${ }^{7}$ Nevertheless, the emphasis was on hard work and behaviour appropriate to their calling; only when they had qualified were the medical students free to give active support to the suffrage cause. And even then they had to strike a careful balance between their political beliefs and the dignity of their profession. As a result, the number of doctors who took militant action was fairly small; for the most part, medical women who supported the militants did so without participating in the flamboyant stunts dreamt up by the WSPU, which might expose them to charges of lack of decorum. This strategy had the blessing of the WSPU leadership: the young Letitia Fairfield consulted Mrs Pankhurst about the tension between her desire to help the WSPU and her efforts to forge a career as a doctor ("I belong to a very difficult profession that is fighting its own battles every day where if you're not a success you're an absolute failure"), and was firmly advised that the organization had "plenty of volunteers", that she would be much more use to it if she "kept her status in the medical profession". ${ }^{8}$ Accordingly, while relatively few doctors figure in

\footnotetext{
${ }^{5}$ For example, in a 1908 poll of women doctors, 538 voted in favour of suffrage for women, and only 15 against (Brian Harrison, 'Women's health and the women's movement in Britain: 1840-1940', in Charles Webster (ed.), Biology, medicine and society 1840-1940, Cambridge University Press, 1981, pp. 15-72, p. 51).

${ }^{6}$ Report of the LSMW inaugural address for the 1904-5 academic year by Dr Mary
}

Murdoch, Lancet, 15 Oct. 1904, ii: 1073-4, p. 1074

${ }^{7}$ University of Melbourne, Vera ScantleburyBrown Archive, Letter-Diaries from England, Box 84/82 (hereafter VSLD), Volume A3, p. 15.

${ }^{8}$ Women's Library, Oral Evidence on the Suffragette and Suffragist Movements: Letitia Fairfield, tape recorded interview with Brian Harrison, 31 Dec. 1976, 8SUF/B/118. 


\section{Jennian F Geddes}

newspaper accounts of militant action, many of them participated in events such as the large set-piece marches and demonstrations. Two of the most active medical supporters of the WSPU were Louisa Garrett Anderson and Flora Murray, alumnae of the LSMW, and founders of the Women's Hospital Corps.

Louisa Garrett Anderson was forty-one when war broke out in 1914. She had been qualified for seventeen years, and was working both at the Women's Hospital for Children, of which she was co-founder, and at the New Hospital for Women, started by her mother, Elizabeth Garrett Anderson. Anderson had been a member of several National Union of Women's Suffrage Societies, as well as the WSPU. Her activities in the women's movement before the war had included taking part in the large suffrage processions, hosting the first meeting of the Women's Tax Resistance League, chairing the inaugural meeting of the London Graduates' Union for Women's Suffrage, and being Vice-President of the United Suffragists. A woman of independent means, the WSPU annual reports show that she regularly made substantial financial contributions to the organization. On 4 March 1912, after much careful deliberation, she risked both her personal and her professional reputation by breaking a window of a house in Knightsbridge in protest at a speech made by an anti-suffrage Cabinet minister. She was arrested, and sentenced to six weeks' hard labour (subsequently reduced to four weeks, through the intervention of influential friends. ${ }^{9}$ ) Letters to her mother smuggled out of Holloway ${ }^{10}$ show that her experiences in prison cemented her commitment to the women's movement and, although she left the WSPU in 1913 with others disenchanted with the Pankhurst leadership, she remained active in nonviolent militant groups up to the start of the war. Anderson's obituary, written by the suffragist Evelyn Sharp, described her as "one of the great persons of the so-called women's movement", whose "consciousness of her own importance in it was never emphasized by her and might, therefore, receive less than its due recognition from the young women of today, who owe so much of their liberty to action like hers." 11

We know much less about Anderson's friend and long-term companion, Flora Murray. Four years older, Murray trained at the LSMW after Anderson but finished her course at Durham, and then worked in Scotland before returning to London in 1905 first as medical officer at the Belgrave Hospital for Children and then as anaesthetist at the Chelsea Hospital for Women. Murray joined the WSPU in 1908, and soon found herself physician to the militants. She marched in their processions and provided first aid for casualties in the suffragette demonstrations. She campaigned with other doctors against the forcible feeding of prisoners, and looked after Mrs Pankhurst and other hunger-strikers after their release from prison, at the nursing home run by Nurse Pine. ${ }^{12}$ Both she and Louisa Garrett Anderson often spoke at suffrage meetings and rallies, and newspaper reports show that Murray frequently addressed other meetings on a range of feminist issues. At the beginning of 1912 the two women together founded a small hospital, the Women's

\footnotetext{
${ }^{9}$ Acknowledged by Anderson shortly after her release, in a speech reported in Votes for Women, 26 Apr. 1912, p. 467.

${ }^{10}$ Women's Library, Louisa Garrett Anderson Papers (hereafter WLLGAP), Letters from Holloway Prison, $7 \mathrm{LGA} / 1 / 2$.
}

\footnotetext{
${ }^{11}$ Evelyn Sharp, 'Dr Louisa Garrett Anderson', Manchester Guardian, 17 Nov. 1943.

12 'A women's military hospital', The Suffragette, 16 Apr. 1915, p. 13, describes Murray as "honorary physician" to the WSPU; Elizabeth Crawford, The women's suffrage movement: a reference guide, 18661928, London, Routledge, 2001, p. 432.
} 


\section{The Suffrage Military Hospital in Endell Street}

Hospital for Children, at 688 Harrow Road. As well as providing health care to workingclass children of the area, they were aiming to give women doctors an opportunity to gain clinical experience in paediatrics, there being at that time no children's hospital in London that offered appointments for women. ${ }^{13}$ Their third motive for doing so is indicated by the motto they chose for their hospital, which was the slogan of the WSPU, "Deeds not Words". This was the same motto that they were later to adopt for the WHC.

The Women's Hospital Corps, its medical staff composed entirely of LSMW graduates, ${ }^{14}$ was the first women's unit to go into service, on 15 September 1914. It successfully ran a voluntary military hospital at the Hôtel Claridge, in Paris, and then a couple of months later at the request of the RAMC opened a second hospital in Wimereux, the first women's hospital to be recognized by the army. Because they were entirely run by women, both hospitals inevitably attracted attention, mostly favourable: the newspapers and journals of the day reported the activities of the Corps widely, but more often than not in the hagiographic style typical of most contemporary reports of women's war work. A report in the British Medical Journal one month after the Hôtel Claridge opened will have been more prized by Murray and Anderson, indicating as it did a degree of acceptance by their peers: "if this institution were the sole British hospital in Paris the medical profession in Great Britain might still continue to regard itself as well represented". 15

By Christmas 1914, however, the War Office began to plan to treat casualties in England rather than France, and so to create a large number of new hospital beds at home. Many units in France were closing. Murray and Anderson offered their services to the army, and arrangements were made for the two women to meet Sir Alfred Keogh, Director General of Army Medical Services, at the War Office, who immediately offered them the chance to run a large hospital in London of between 500 and 1000 beds, working for the RAMC. Murray and Anderson accepted with alacrity, shut both hospitals in France and brought the Corps back to England. The premises they were to be offered were those of the former St Giles Union Workhouse in Endell Street, Covent Garden.

\section{A Regular Military Hospital}

An offer of employment to women doctors by the Director General of the RAMC may seem surprising in view of the opposition encountered by medical women trying to volunteer in August 1914, but by early 1915 circumstances were very different. Keogh, a supporter of the LSMW, had been appointed the previous October to reorganize the evacuation and treatment of casualties after a disastrous start to the war by the RAMC. ${ }^{16}$ His plans included a huge increase in beds in the UK, and having received good reports of the WHC's hospitals in France he had no hesitation in offering the Corps a military hospital in London. Nevertheless, this did constitute a leap of faith, because the enterprise at Endell Street was to be of a different order from anything the WHC had done

\footnotetext{
${ }^{13}$ A H Bennett, English medical women: glimpses of their work in peace and war, London, Sir Isaac Pitman \& Sons, 1915, pp. 68-9; Flora Murray, 'The position of women in medicine and surgery', New Statesman, 1913, 1 (supp): xvi-xvii.

${ }^{14}$ Details of the thirty-seven doctors known to have served in the Women's Hospital Corps are given in
}

Geddes, “"Women as army surgeons" ', op. cit., note 1 above, Appendix B.

${ }^{15}$ Br. med. J., 1914, ii: 767.

${ }^{16}$ Churchill Archive Centre, Churchill College, Cambridge, Lord Esher's War Journals, August 1914 to January 1915: 'Memo for Lord K: The War Office and the Red Cross' (undated, Sept. 1914), ESHR 2/13. 


\section{Jennian F Geddes}

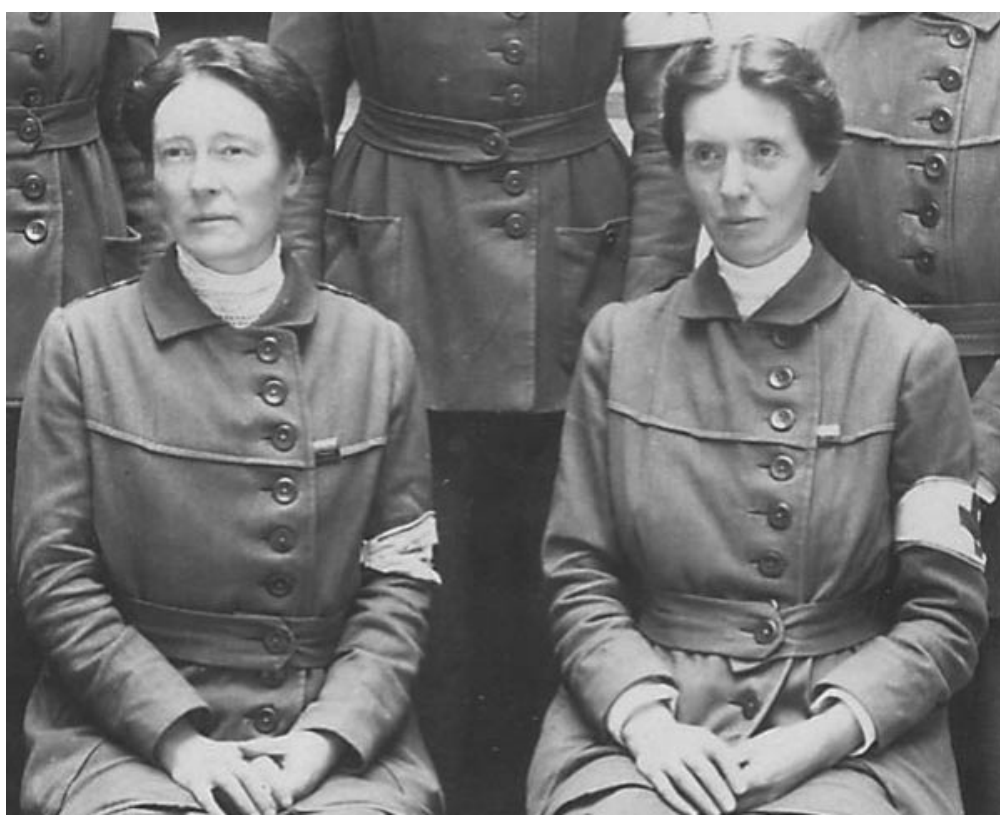

Figure 1: Louisa Garrett Anderson (left) and Flora Murray (right), from a group photograph of the WHC taken outside the Hôtel Claridge in early October 1914. The uniform was designed by the two women, and rectangular WSPU badges are clearly visible to the right of the line of buttons. In the original photo, two of the other five doctors can be seen to be wearing suffrage badges, though not WSPU ones (photograph courtesy of the Anderson family; original now in the Women's Library).

so far. From the outset, many of the RAMC hierarchy were sceptical about the hospital's success, and no one was more conscious than Murray and Anderson of the magnitude of what they had undertaken, and of the opposition that they would encounter:

... in the years which followed, the doctors realised how much these War Office officials could and should have done to help them in those early days, and how they did as little as possible.... Advice and assistance were withheld, lest the officer who gave it might in some way become responsible for the women's affairs; in addition, their path was often obstructed. It was not understood at the time that obstruction was due to hostility. ${ }^{17}$

The antagonism between Endell Street and the RAMC was very real, and it soon became clear that the WHC could not expect help from the RAMC personnel with whom it dealt. The women needed colleagues who sympathized with their aims. Some of those who had served with the Corps in France volunteered to work in London, and the selection of additional doctors was quickly made through the network of LSMW graduates. Surgeons and physicians/anaesthetists, as well as a pathologist, a dentist, a radiologist and an ophthalmic surgeon were recruited. ${ }^{18}$ The New Hospital for Women lent their matron to Endell Street, and she and Murray and Anderson between them conducted around a thousand interviews in early 1915 , searching for suitable non-medical staff. ${ }^{19}$ The highly

\footnotetext{
${ }^{17}$ Murray, op. cit., note 1 above, pp. 127-8.

${ }^{18}$ Geddes, "Women as army surgeons", note 1 above, Appendix B.
}

${ }^{19}$ Grace Hale, 'The women's hospital corps', St Bartholomew's Hospital League News, Mar. 1917, pp. 755-8, 757. 
focused philosophy of the Corps was spelled out clearly to those who joined: "We had this drilled into us: you not only have got to do a good job but you have got to do a superior job. What would be accepted from a man will not be accepted from a woman. You have got to do better." 20 By mid-May 1915, when the first patients arrived, the hospital had a full complement of staff. Murray was Doctor in Charge; Anderson was Chief Surgeon. They had with them around 15 doctors, including visiting specialists, 36 nurses, 80 orderlies, an unspecified number of clerks, cooks and cleaners, a Quartermaster, storekeepers, a Transport Officer and a Steward, and were supported by an RAMC detachment of 21 men-most of whom were unfit for active service and so of relatively little use. ${ }^{21}$ As well as a full-time staff, a large number of volunteers were found to act as librarians, entertainment officers, gardeners, ward visitors, and so on. Many of them had worked with Murray and Anderson in the women's movement before the war.

Army bureaucracy came as a rude shock to women who were accustomed to organizing their own hospitals, and it is clear from several sources that the early days were far from easy. Sir Alfred Keogh arranged for the two Commanding Officers to go on a course at Millbank to learn how to run a military hospital, but otherwise the Corps was left to fend for itself, tolerated solely because it was under the Director General's patronage. The RAMC was reluctant to find itself responsible for the hospital, certain that it would not last more than six months. ${ }^{22}$ Convoys of casualties poured in from the moment the hospital opened. The original 520 beds were very soon increased to 573. By 1919, when the hospital closed, the Corps had acquired three auxiliary hospitals in north London, giving the women control of nearly 800 beds in all. ${ }^{23}$ Endell Street's proximity to the railway stations to which the ambulance trains came meant that inevitably it was one of the first hospitals to receive convoys arriving in the country. Between thirty and fifty soldiers at a time, sometimes as many as eighty, ${ }^{24}$ would be delivered, often late at night. Many had to be taken immediately to theatre, and it was not unusual for the surgeons to perform over twenty operations a day. Nothing that the women surgeons had seen before the war could have given them the experience needed to treat the injuries caused by trench warfare. So far as I can ascertain, when the war started Anderson was the only member of the WHC to have previously held a surgical appointment at an adult hospital, as assistant surgeon for outpatients at the New Hospital for Women. The annual reports of that hospital enable us to appreciate quite how surgically inexperienced she would have been: 1914 saw 437 major operations performed on inpatients at the New Hospital, only 142 of which were non-gynaecological. Apart from 58 appendicectomies, the two most frequently performed general surgical procedures that year were cystoscopy (15 patients) and drainage of cervical abscess (14) ${ }^{25}$ In outpatients

\footnotetext{
${ }^{20}$ Franklin D Roosevelt Presidential Library, Hyde Park, NY, Marion Dickerman Papers, Transcript of an interview with Marion Dickerman by Jennifer Starr, p. 13. The American feminist came over with her friend Nancy Cook in 1918 to work as a nursing orderly at Endell Street.

${ }^{21}$ Imperial War Museum (hereafter IWM), Women's Work Collection (hereafter WWC), MUN 18.6, Ministry of Munitions Committee for the Organisation of Women's Services, 8.12.16, Evidence of Dr Flora Murray, p. 43.
}

\footnotetext{
${ }^{22}$ Hale, op. cit., note 19 above, p. 757; also Wellcome Library, Archives and Manuscripts, Medical Women's Federation Archives, SA/MWF/C.168, account of Endell Street by Dr Winifred Buckley, pp. 5.

${ }^{23}$ Buckley, op. cit., note 22 above, p. 7.

${ }^{24}$ IWM, WWC MUN 18.6, cited note 21 above, p. 50.

${ }^{25}$ London Metropolitan Archives, Annual report of the New Hospital for Women for 1914: H13/EGA/8/1, pp. 19-27.
} 


\section{Jennian F Geddes}

Anderson would have been able to do only minor operations, and even had she assisted with some of the larger cases they would hardly have constituted a suitable training for major trauma surgery.

Many of the casualties arriving at Endell Street needed major abdominal surgery, and in the first couple of years there were also severe head injuries, some requiring craniotomy. Long bone fractures with severe soft tissue lacerations were common, with the result that a considerable proportion of cases were orthopaedic: at one time there were 154 men with a compound fracture of femur on the wards. ${ }^{26}$ Later in the war, head injuries and fractures of femur were diverted to specialist units, but a large number of amputees, for whom the staff became proficient at making prostheses, still passed through the hospital. ${ }^{27}$ Wound infection was a major complication of all injuries, and the women experimented with different treatment regimens. The pathologist Helen Chambers, a gold medallist from LSMW, was a central member of the clinical team: regular meetings were held in her lab, at which the results of cultures of patients' wound swabs and their management were discussed. Chambers' collaboration enabled Anderson to carry out clinical research, reported in four scientific papers, one of which described a trial of a new bacteriostatic compound that appeared to reduce significantly the frequency with which surgical dressings needed to be changed - a major consideration in any military hospital of the day. The importance of the women's research is indicated by the fact that Sir Alfred Keogh himself paid a visit to the hospital specifically to inspect their methods. ${ }^{28}$ Other women not working at Endell Street also took the opportunity to do research at the hospital: two physiologists on the staff at the LSMW, Winifred Cullis and Enid Tribe, studied the lung function of men with chest injuries by analysing air they exhaled. ${ }^{29}$

The First World War was, of course, providing a huge impetus for medical research, ${ }^{30}$ and for women serving on the wards and in the laboratories of military hospitals this was effectively the first opportunity for them to do this. In all, seven papers from Endell Street staff were published in the Lancet. From the SWH, Frances Ivens, Médecin Chef at the hospital at Royaumont - the only other women's hospital in which conditions were suitable for research - analysed a series of cases of anaerobic infection, and collaborated with the Institut Pasteur in trials of gas gangrene antiserum, publishing her experience with both. ${ }^{31}$ Between them, Endell Street and Royaumont produced the first hospital-based research papers published by British women doctors. In doing so they were making a significant incursion into the sphere of "male" medicine, for scientific research had up until then been a strictly masculine endeavour, with women doctors' publications tending to be restricted to case studies, technical reports or small case series. ${ }^{32}$

\footnotetext{
${ }^{26}$ Murray, op. cit., note 1 above, p. 162

${ }^{27}$ Interview with Marion Dickerman, cited note 20 above, p. 4.

${ }^{28}$ Murray, op. cit., note 1 above, p. 165. A full list of Endell Street publications is given in Geddes, "Women as army surgeons", op. cit., note 1 above.

${ }^{29}$ Winifrid Cullis and Enid Tribe's work, funded by the Medical Research Committee, was published in Lancet, 1915, ii: 912-13.
}

\footnotetext{
${ }^{30} \mathrm{See}$, for example, the 4 th annual report of the Medical Research Committee, 1917-18.

${ }^{31}$ See Eileen Crofton, The women of Royaumont: a Scottish women's hospital on the western front, East Linton, Tuckwell Press, 1996, Appendix 2, for details of the research carried out at Royaumont.

${ }^{32}$ Royal Free Archive Centre, annual reports of the LSMW.
} 


\section{The Suffrage Military Hospital in Endell Street}

\section{"Cheerful and Curative Influences"}

Endell Street's status as an official military hospital was a source of pride to its Commanding Officers, and Murray was keen to emphasize that it was "exactly like every other military hospital", using this as the reason for forbidding the Imperial War Museum to include it in their Women's Work Collection, declaring that she did not want her hospital to be confused with "other hospitals run by non-professional women". ${ }^{33}$ Despite the fact that it set out to be a professionally run army hospital, however, it was not "exactly like every other military hospital". Many distinctive "feminine touches" were evident at Endell Street, and it had a warm ambiance not normally associated with military establishments. We have seen that though officially funded by the army, the women were largely ignored by it, and left to do what they wanted with their military hospital. They succeeded in making concerted efforts to brighten up the lives of the soldiers, and phrases such as "distinctive atmosphere", "cheerful and curative influences", "a wonderful atmosphere of sympathy and home", "nowhere else do you find quite the same atmosphere of gentleness" are common in newspaper articles about the hospital. ${ }^{34}$ As army practice dictated, the seventeen wards were officially named with the letters of the alphabet, but the names actually in everyday use in the hospital were those of female saints: Ward A was "St Anne", Ward B "St Barbara", Ward C "St Catherine", Ward D "St Deborah", and so on. Flowers were to be found in all the rooms, refreshed daily by a team of volunteers led by Anderson's sister-in-law, and brightly coloured blankets-different in each of the wardswere a striking touch not seen in the drab wards usual in a military hospital. Additional luxuries, such as the consignment of standard lamps donated by St Leonard's School for the patients to read by, made the contrast even greater. Undoubtedly, journalists tended to emphasize such aspects of the Endell Street Military Hospital in order to highlight the hospital's respectability and to gloss over the unusual nature of the enterprise, but even so it does appear that concern for the psychological welfare of the patients was an important and real feature of WHC work. The suffragist Evelyn Sharp, visiting the Corps in Wimereux, commented on "the special understanding shown by the staff of the psychology of their patients". ${ }^{35}$ Even in the chaotic early days at the Hôtel Claridge, Anderson had told her mother that, while she was valuing the opportunity to expand her clinical skills, her patients needed more than medical intervention:

I like still more the opportunity of being a little good to these bruised men. Their minds are full of horrors and it is a help to them to come into a soothing atmosphere with decent food and soft beds and our gentle merry young orderly girls who feed them with cigarettes and write to their mothers and read to them.... We are going to have Scotch songs tomorrow instead of hymns and I fear even a gramophone may appear for a short time. All the men are shocked by what they have been through - and normal comforts and little pleasures are a help to them and make them sleep and forget a little. ${ }^{36}$

${ }^{33}$ IWM, WWC MUN 18.6, cited note 21 above, p. 44; her refusal is recorded in a brief note of a meeting between Murray and Agnes Conway, from the IWM: WWC, BRC 24.1/2, Agnes Conway, 'Interview at Endell Street Hospital, 7 December 1917'.

${ }^{34}$ Phrases from different press cuttings in Flora Murray's scrapbook, WLLGAP, 7LGA/3.

\footnotetext{
${ }^{35}$ Evelyn Sharp, Unfinished adventure: selected reminiscences from an Englishwoman's life, London, John Lane, Bodley Head, 1933, p. 160.

${ }^{36}$ WLLGAP, 7LGA/2/1/08 and 7LGA/2/1/09, Letters from the Woman's Hospital Corps (hereafter WHC), 22 and 27 Sept. 1914.
} 


\section{Jennian F Geddes}

It is difficult to see "soft beds", "little pleasures" and "gentle merry young orderlies" being high on the list of therapeutic priorities for other army hospitals. But as Anderson had made clear in a confident speech the week Endell Street opened, running a successful hospital involved maternal responsibilities and skills as well as professional and administrative skills:

"After all," she said, "if you have found out the way to treat children-what toys they like, what they like for tea, and what frightens them when going to an operation-you have gone a great way to find out how to run a military hospital." (Laughter) "My hospital when complete will have 550 beds - 550 large babies requiring a great deal of care, a great deal of understanding, and a certain amount of treatment." (Laughter). ${ }^{37}$

The claim by a group of mainly single professional women to have maternal obligations towards their soldier patients, whom they describe as "babies", subverts traditional stereotyping in which women doctors were not seen as having either a military role, or a role as doctors to men. Anderson's use of familial imagery, coupled with her argument that women would know best how to treat the wounded, at the same time justified and conferred respectability on the Corps' new venture.

It is of course difficult to assess from newspaper reports of the day or from accounts by members of the WHC and their suffragette friends exactly how much Endell Street differed from the male-run military hospitals in its attention to patients' psychological needs. Theatricals, Christmas shows, concerts, athletics events were all regular features at other RAMC and voluntary hospitals, most of which also would also have a committee of volunteers which raised funds for items like cigarettes, books, periodicals and games for the patients, and organized the activities. In at least one military hospital soldiers were encouraged by visiting ladies to try needlework and embroider their regimental badges. ${ }^{38}$ Nevertheless, it is clear that the number of activities, social functions, particularly concerts and entertainments, was unusual, and surprised visitors to Endell Street. In the centre of London, the hospital staff had ready access to both facilities and volunteers, and thanks to their many middle-class patrons there would have been no shortage of funds to call on. Gardeners ensured a constant display of flowers in tubs to brighten the courtyard. The hospital boasted a large library, and a hall with a stage which had the hospital's suffrage motto painted over its proscenium arch. ${ }^{39}$ Many celebrated actors and actresses were persuaded to perform there: according to Murray, over 1000 performers visited Endell Street each year, and in the four years it was open, 511 entertainments were arranged. ${ }^{40}$ Sports days featured crawling and cigarette races for the less able, as well as boxing exhibitions, while on the wards needlework classes were popular, many of the soldiers developing considerable skill with the needle. The men were encouraged by the regular sales of their work that were held at the hospital, attended by society ladies and

\footnotetext{
37 'Soldiers as patients: "large babies", , Daily Telegraph, 18 May 1915.

${ }^{38}$ John Calder, The vanishing willows: the story of Erskine Hospital, Bishopton, Princess Louise Scottish Hospital, 1982, p. 24; J R Hopkins, 'Leicester's Great War Hospital: The 5th Northern General Military Hospital, Leicester (1914-19)', MA thesis, University of Leicester, 1995, p. 48 (held at the Wellcome
}

Library); the embroidery is illustrated in Arthur R Smith, From battlefield to blighty: Frodsham Auxiliary Military Hospital 1915-1919, Wirral, Avid Publications, 2001, p. 62.

${ }^{39}$ Murray, op. cit., note 1 above, p. 139.

${ }^{40}$ Ibid., p. 190. Reports in the Court Circular in The Times list many well known names. 


\section{The Suffrage Military Hospital in Endell Street}

occasionally by members of the Royal Family. Christmas time saw intense inter-ward competition for the best-decorated ward, many of the decorations being extremely elaborate. ${ }^{41}$ "We want [the men] to feel rested and refreshed in their spirits by staying here", 42 said Anderson in a letter to her old school; she clearly did not feel that using the empathic and patient-orientated skills that women doctors were traditionally supposed to possess was at odds with aims of an RAMC hospital.

\section{Military Medicine as Suffrage Work}

The Commanding Officers of the WHC frequently specifically linked their military work with suffrage work. Like other middle-class women in 1914, raised on concepts such as duty and patriotism, Murray and Anderson would undoubtedly have been eager to volunteer, and to offer their professional skills; as suffragists, they would see that providing medical services to the troops would give women an opportunity to prove that they were capable of playing their part as citizens. They were confident that they could be army surgeons, and they would be. Their work was a continuation of their suffrage endeavours: "After years of unpopularity over the suffrage", Anderson wrote to her mother from Paris, "it is very exhilarating to be on the top of the wave, helped and approved by everyone, except perhaps the English War Office! While all the time we are still doing suffrage work-or women's work-in another form". ${ }^{43}$ The use of the term "women's work" to describe military medicine, an archetypal male activity, is startling, particularly since in this war military medicine consisted almost entirely of performing amputations or patching up terribly mutilated bodies with the sole aim of returning as many men as possible to the slaughter. The paradox of women doing such work was not lost on Evelyn Sharp who in her account of a visit to the Corps at Wimereux commented on,

... the bitter irony of our civilisation, which first compels men to tear one another to pieces like wild beasts for no personal reason, and then applies all its arts to patching them up in order to let them do it all over again.... somehow, when the patching is done by women the ironic tragedy of the whole thing seems more evident. ${ }^{44}$

The choice of the WSPU motto, "Deeds not Words", by Murray and Anderson for their hospitals was a natural one, given their support of that organization. Both Murray and Anderson wore their WSPU badges whenever they wore their WHC uniform, ${ }^{45}$ seeing the WHC as a direct link with their militant past. Indeed, it is known that the WSPU did continue to provide some financial support to the WHC, even though it was not an official sponsor. ${ }^{46}$ It is quite usual in contemporary press reports about Endell Street to find references to the doctors' former militant activities, demonstrating that the public perceived the hospital to be a feminist one. ${ }^{47}$ According to the American actress Elizabeth

\footnotetext{
${ }^{41}$ A detailed description of the 1917 Christmas decorations, and the awarding of prizes, is given by Vera Scantlebury (VSLD, Volume A8, pp. 44-9).

${ }^{42}$ Letter from LGA to Hilda Milne, St Leonard's School Gazette, 1916, p. 196.

${ }^{43}$ WLLGAP 7 LGA/2/1/09, Letters from the WHC, 27 Sept. 1914.

${ }^{44}$ Sharp, op. cit., note 35 above, p. 160.
}

\footnotetext{
${ }^{45}$ Murray, op. cit., note 1 above, p. 56. See Figures 1 and 2.

${ }^{46}$ Elizabeth Robins, Ancilla's share: an indictment of sex antagonism, London, Hutchinson, 1924, p. 253.

${ }^{47}$ Tatler referred to it as "the Suffragette hospital" (WLLGAP 7LGA/3, cutting in Murray's scrapbook).
} 


\section{Jennian F Geddes}

Robins, who briefly served at Endell Street, Anderson attributed the success of the WHC to the training the women had gained in the WSPU years. ${ }^{48}$ And it is evident that, despite what Murray piously claims in her book ("as their motto was 'Deeds not Words', they never attempted propaganda, even with their colleagues" 49 ), the suffragists in the group did in fact proselytize continuously among staff and patients at Endell Street. Very soon after her arrival at the hospital, Vera Scantlebury wrote to her parents in mock alarm "You did not know that I am in the midst of the very militant suffragettes, did you? Well quite true. There was your innocent harmless little daughter closed in a room with two of them."

The staff at Endell Street were encouraged to regard what they were doing as a positive contribution to the women's cause, and a preparation for the day when women would finally obtain the vote. Regular educational meetings were held:

I have just spent a very interesting hour with the orderlies in their Common Room where Dr Murray was telling them about Mary Summerville [sic] a famous woman who wrote books on astronomy and physical geography in spite of the fact that such things were "not done" by "ladies" in those days... . Dr Murray gives these little lectures every Friday night to the orderlies, "educating their future citizenesses", as Dr Anderson explained ... 51

Training the women under their command was a logical consequence of the Commanding Officers' belief that professional women had responsibilities to be leaders. They believed it was important to make time in the hectic hospital schedule to do so: "By virtue of our training, it is our duty to lead other women", Anderson exhorted medical students in her LSMW inaugural address in October 1917, "Do not let your personal preference for professional work or a quiet life hinder you from accepting responsibility when the demand comes", 52

Vera Scantlebury wrote long letters home during her eighteen months at Endell Street. They reveal that suffrage and other women's issues were widely discussed in the hospital, both with patients on the wards, and among the doctors when off duty. Over three-quarters of the medical staff had trained at the LSMW which, according to the young Australian, was a hot-bed of feminism. ${ }^{53}$ In addition, several of the older staff had been members of the WSPU and other militant organizations, while the volunteers included the former militant Beatrice Harraden as librarian with Elizabeth Robins, another ex-WSPU member, as her assistant. "Amusements" were organized by Bessie Hatton, also a WSPU supporter, who had founded the Women Writers' Suffrage League. Given these personalities, it is not surprising that women's issues were high on the agenda. Not entirely sympathetic to the militant cause, Scantlebury had reason to complain:

Dr Murray came into afternoon tea with us and we had a long talk-again the suffragettes, the IWWs and the Pankhursts-somehow or other we always get around to that subject again and again ... They all tell me that I shall be on a platform sooner or later! So beware, my family—much love from Your Militant Suffragette. ${ }^{54}$

\footnotetext{
${ }^{48}$ New York University Libraries, Fales Library and Special Collections, Papers of Elizabeth Robins, Diary for 1915 (MSS 2; Series 1A; box 6, entry for 10 May, 1915).

${ }^{49}$ Murray, op. cit., note 1 above, p. 56.

${ }^{50}$ VSLD, Volume A2, p. 61.

${ }^{51}$ VSLD, Volume A10, p. 35.
}

\footnotetext{
${ }^{52}$ Magazine of the London (Royal Free Hospital) School of Medicine for Women, Nov. 1917, 12 (68): 80. ${ }^{53}$ VSLD, Volume A3, p. 15.

${ }^{54}$ The Industrial Workers of the World was a radical labour movement founded in the USA in 1905; VSLD, Volume A3, p. 4-5.
} 


\section{The Suffrage Military Hospital in Endell Street}

Despite the harangues of her Commanding Officers (viewed with some detachment by the recruit from a country in which women were already enfranchised), Scantlebury nevertheless respected their goals as well as their achievements:

I have the greatest admiration and respect for these two women. They have struggled against fearful odds and have succeeded beyond all expectations against the greatest prejudice.... From an old ramshackle of a place and against fearful odds they have made this hospital.... Our COs are wonderful brave hard working women and their [sic] must be something in the cries for women $\left[\right.$ sic] suffrage if such women take it so seriously. ${ }^{55}$

Because the work of the WHC was an integral part of the struggle for equality for women, Murray and Anderson tried to make sure that their achievements would be recorded for posterity. As leaders of other campaigns had done before them-notably the WSPU during the militant years-they commissioned a medal to commemorate the Corps' exploits in France. Presumably given to every member of the original band, the medal was to provide a lasting souvenir of their work; one survives in the possession of the family of a doctor who joined the WHC in October 1914. Photographs too, were propaganda essentials: Murray and Anderson must have regularly arranged for photographers to take pictures at Endell Street, because many high-quality photographs of daily life at the hospital survive in family albums. The two women kept a scrapbook in which they pasted press cuttings about their work, supplied by an agency. ${ }^{56}$ Murray's book, written in 1920, was, however, to be the most important record of their war work. ${ }^{57}$ By recounting the story herself, Murray was able to produce her history of the Corps, and, not unsurprisingly, it is a selective account. There is nothing about the impact of the war on the women or about the many medical difficulties the doctors must have found themselves in through inexperience, and the names of several members of the Corps were omitted. Not only those who only worked for a few months, but all the women from overseas, even those who stayed for nearly two years, were deliberately left out. The omission rankled:

She mentioned by name every English, Scottish and Irish Doctor who was ever there, but not one Australian. Whether she liked Australians or not, she never mentioned any of us ... Everybody tried to make her alter her mind. She said "No. She was writing about an English thing and she would only mention those". 58

In 1920, with only partial suffrage gained for women, it appears that in order to maximize the impact of the story it was politically necessary to present the Corps' wartime work as exclusively that of British women-much as official histories of the war tended to minimize the contribution of overseas combatants in order to give prominence to the British contribution.

Public recognition in fact came very soon after Endell Street opened in 1915. Its unique status, a military hospital run by women, made the hospital a favourite subject for press articles. Louisa Garrett Anderson's own social standing-daughter of Elizabeth, niece of Millicent Fawcett, sister of the Controller of the Navy, cousin of two members of Lloyd George's Cabinet and of the Chief Controller of the WAAC ${ }^{59}$ - would not have been a

\footnotetext{
${ }^{55}$ VSLD, Volume A2, p. 62.

${ }^{56}$ WLLGAP 7LGA/3.

${ }^{57}$ Murray, op. cit., note 1 above.
}

\footnotetext{
${ }^{58}$ University of Sydney Archives, Australia: Biographical File 955, Elizabeth Hamilton-Browne. ${ }^{59}$ LGA's brother, Alan Anderson, was civilian Controller at the Admiralty in 1917; her cousins were
} 


\section{Jennian F Geddes}

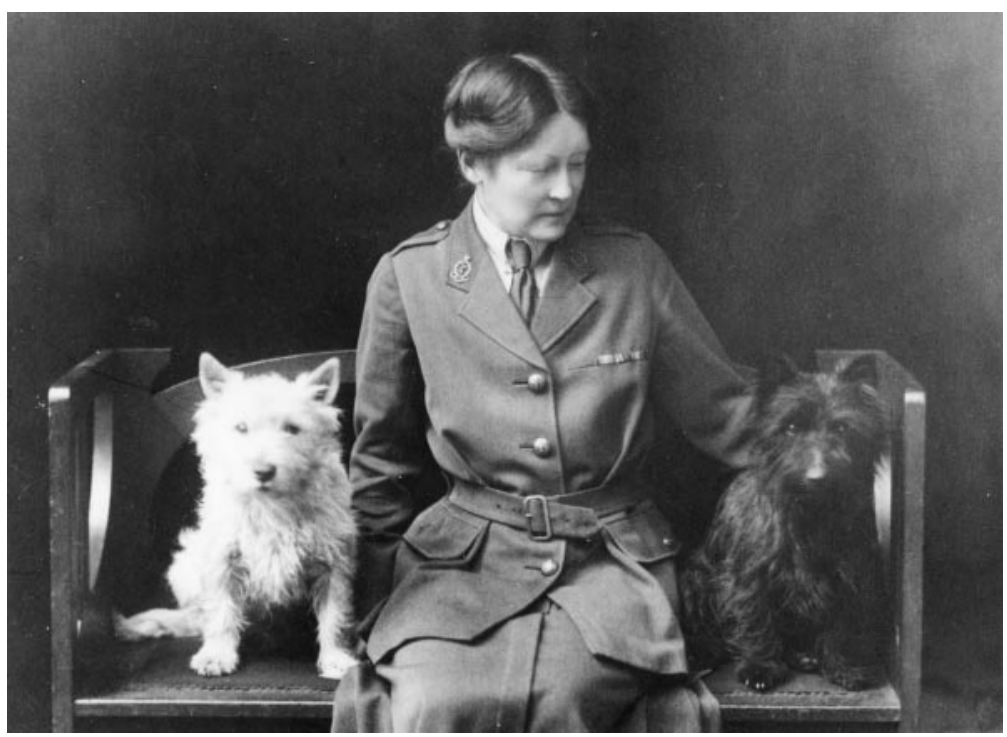

Figure 2: Louisa Garrett Anderson, probably taken around 1918. Once the Corps was associated with the RAMC, the doctors tended also to wear this military-style outfit, with RAMC badges on the lapels. Campaign ribbons were worn, but not suffrage badges. However, when they went to Buckingham Palace in 1917 to receive the CBE, Murray and Anderson reverted to their WHC uniforms (photograph courtesy of the Anderson family; original now in the Women's Library).

disadvantage in this respect. A combination of influential patronage and the fact that Endell Street continued to flourish despite all dire RAMC predictions to the contrary slowly converted the army hierarchy. Establishment recognition also came well before the end of the war. In 1917, in the first Honours List for the new Order of the British Empire, Murray and Anderson were awarded the CBE, and over the next few years four more of the Endell Street doctors were awarded either a CBE or an OBE. The following year the Representation of the People Act gave women over thirty the vote, and Endell Street staff celebrated by hoisting the WSPU flag with other flags in the hospital courtyard. The vote had been won, albeit in a rather more limited form than suffragists had wanted; the principal remaining goal for the women doctors of the WHC was that of recognition by their peers after the war was ended.

Despite the undoubted success of the Endell Street hospital in the public's eyes, it seems that the goal of occupational equality for women doctors remained elusive. It is interesting that while Murray and Anderson, like other suffragists serving during the war, pinned WSPU badges on to their uniform in autumn 1914, they never appear to have worn them on the very military-style dress they assumed once the WHC became part of the army medical services the following year (see Figure 2). ${ }^{60}$ It is possible that once they were at Endell Street the issues of professionalism and acceptance by their RAMC peers became as

Sir Eric Geddes, First Lord of the Admiralty, Sir Auckland Geddes, Minister of National Service, and Dr Mona Chalmers-Watson, Chief Controller of the WAAC.

\footnotetext{
${ }^{60}$ There are many photographs surviving in Murray's book and in private collections, showing the women in both RAMC and WHC uniform, which would support this.
} 


\section{The Suffrage Military Hospital in Endell Street}

important as their suffrage agenda. Such an interpretation would be supported by the outcry provoked by a drawing by one of the official war artists, revealing as it does just how important such acceptance was to them. ${ }^{61}$

\section{Professional Women Misrepresented}

Early in 1919, as part of the Imperial War Museum's efforts to record the medical history of the war, the artist Austin Spare was sent to do some drawings at Endell Street. One of his completed pictures, a pastel of an operation in progress, was exhibited at the Royal Academy later that year. The only record of this work today is a photograph, since the original is no longer in the IWM collection. Having seen the picture in the exhibition, Flora Murray wrote to the museum complaining that Spare's picture was a caricature, and asking if it could be destroyed.

The picture does not pretend to have any artistic merit, but rather to be an illustration of work done by women in the Endell Street Hospital.... As it stands, the picture is a misrepresentation of the work of professional women. It is full of errors, which, though they may not strike the lay person, make it an object of ridicule to all those who have some professional knowledge.

... It is very painful to all those of us who worked at Endell Street to see such a picture hung. We would rather have no record of our work than a false record; and Dr Garrett Anderson and I must earnestly ask you to do all you can to have this picture destroyed.... The credit of women surgeons is at stake. ${ }^{62}$

The Women's Work Subcommittee was sympathetic to Flora Murray's views. Its chairman, Lady Norman, wrote to the artist, saying that the two doctors "would prefer not to have the picture shown at all rather than as it is at present, which they say makes their work look ludicrous to the technical mind", and detailing the extensive revisions that they were demanding:

... What we would ask you to do would be to cut the floor off the picture so as to remove the various things so out of place in an operating room, such as the couch, Thomas' splint, the sterilising drums and the kneeling figure of the nurse, all of which, Dr Garrett Anderson points out, would not be seen in an operating room, and would indicate a serious professional breach of the most ordinary surgical practice. ${ }^{63}$

Unsurprisingly, Spare refused, and, declaring himself to be "a little astonished" at the request, would not consent to any "mutilation" of his work. ${ }^{64}$ Anticipating such a reply, the museum had already approached Francis Dodd about producing a more acceptable version of the scene, and it is his rather heroic oil painting, bearing absolutely no resemblance to the Endell Street theatre, which is the principal official record of the WHC today in the collection of the Imperial War Museum. ${ }^{65}$

${ }^{61}$ See Geddes, 'Artistic integrity and feminist spin', op. cit., note 1 above, p. 617-18.

${ }^{62}$ IWM Central Archive, Papers of the Women's Work Collection Subcommittee, EN1 WW Annex (5A/3) Hospitals/Endell Street, Letter from Flora Murray to Lady Norman, 3 Mar., 1920; the file contains an earlier letter on the same subject from Murray to Colonel Brereton, 22 Feb. 1920.
${ }^{63}$ IWM Department of Art, Correspondence with First World War Artists, 29-2, Letter from Lady Norman to Austin Spare, 22 May 1920.

${ }^{64}$ Ibid., Letter from Austin Spare to Lady Norman, 29 May 1920.

${ }^{65}$ An operation at the Military Hospital, Endell Street, Dr Louisa Garrett Anderson, Dr Flora Murray and Dr Winifred Buckley, oil by Francis Dodd, 1921, is 


\section{Jennian F Geddes}

IWM documentation shows that Spare did visit the hospital to see an operation, and a contemporary photograph of the theatre at Endell Street found in several albums compiled by WHC members demonstrates that his picture did faithfully represent the room in question. The artist specifically denied inventing any of the features in his picture-indeed, the details so objected to convey no more than a busy, possibly rather untidy, theatre. Whether or not it was accurate, however, Murray and Anderson considered it made their work look unprofessional, and were not prepared to allow their hospital to be represented in this way. Their protest won the day, and the picture was eventually discarded by the IWM two years later. This extraordinarily vehement reaction to Spare's picture, which Murray and Anderson believed belittled and ridiculed their work, reveals that despite their remarkable and widely-acclaimed contribution to the medical services of the war they knew that there was still some way to go before women would be accepted by the medical profession at large, particularly in surgery. For that reason their work could not be seen as being of anything less than the highest possible standard; it appears that they believed that a small pastel could have undone all the good of the previous four years' work.

\section{Feminists at War}

Women doctors administering and running military hospitals were, possibly to a greater extent than any of their colleagues, in a position to combine their own personal political agendas with highly visible support for their country. A comparison between the WHC and the other women's organizations working in similar circumstances enables us to analyse the way in which different groups handled the balance between their professional involvement in the war and their feminist interests, and helps to throw into relief the radical nature of the WHC's achievements.

A surprising number of women founded voluntary hospitals in the First World War. Such hospitals were established for patriotic reasons, and made no feminist claims whatsoever. Funded and equipped through the efforts of their patron, who was usually titled, they invariably had a male medical officer in charge, and were staffed by male doctors. There were, however, two women's hospital organizations which, like the WHC, differed from the rest in that they had their roots in a feminist-suffragist tradition, and were entirely women-run; the Scottish Women's Hospitals and Mrs Stobart's units. While the WHC aligned overtly with militant organizations such as the WSPU, the SWH was founded by constitutional suffragists in the Scottish Federation of Women's Suffrage Societies. The much smaller and shorter-lived outfits run by Mrs St Clair Stobart were not affiliated with a particular suffrage group, but also had a strongly feminist philosophy. Like the WHC in 1914, both the SWH and Mrs Stobart defied the ban on women doctors working near the front line, and ran a number of successful military hospitals on the Continent. These organizations are most broadly comparable to the WHC, for even though the Corps subsequently became London-based and part of the military establishment, Endell Street remained first and foremost a women's, not an army, hospital. Between them, the three organizations treated many thousands of casualties, providing their female staff with an

currently on permanent loan to the Defence Medical Services Training Centre, Mytchett, Surrey. 


\section{The Suffrage Military Hospital in Endell Street}

extraordinary variety of medical and administrative experience, often in the face of hardship and dangers identical to those faced by men fighting in the war.

Elsie Inglis, the founder and figurehead of the Scottish Women's Hospitals movement, was, like Flora Murray and Louisa Garrett Anderson, a suffragist, though not of militant persuasion. Despite being founded under the auspices of the NUWSS, the SWH differed from both the other two women's hospital organizations in not stressing the connection between its work and the women's movement. In a letter in October 1914, Inglis told Millicent Fawcett that she had deliberately chosen a neutral title for her organization in order to persuade as many women as possible to contribute, even anti-suffragists:

... we must make it clear that our hospitals are as well-equipped and well-manned as any in the field, more economical (easy!) and thoroughly efficient.

I cannot think of anything more calculated to bring home to men the fact that women can help intelligently in any kind of work. So much of our work is done where they can not see it. They'll see every bit of this....

And as the work grows, do let's keep it together, so that however many hospitals we send out they all shall be run on the same lines, and wherever people see the Union Jack with the red, white and green flag below it, they'll know it means efficiency and kindness—and intelligence. ${ }^{66}$

As stated here, her feminist aims appear rather more limited than those of Murray and Anderson; "intelligence", "efficiency and kindness" somehow sound unambitious beside the evangelism of Endell Street and the WHC's oft-repeated mantra of competing to do a job better than a man. This seems to have been true of the entire Scottish Women's Hospitals movement. While their writing paper bore the name of the NUWSS at the top, and there were former WSPU members working in the SWH, there is no doubt that the organizing committee of the SWH were embarrassed by attempts to capitalize on the connection with the suffrage movement. ${ }^{67}$ The attitude is understandable, given the ever-present need to raise funds for their hospitals, something that was not a consideration for the centrally funded WHC.

Mrs Stobart was an entirely different character from Inglis, very much more in the mould of the militant suffragists, believing in "doing", not "talking" —although she denied being either a militant or a suffragist. She was a pacifist who passionately condemned war but at the same time claimed that women could and should contribute to the defence of their country, because the private sphere-women's territory-had now expanded into the public sphere. Women wishing to serve their country had "no desire to relinquish their old ideal of being the 'guardian angels' of their homes", but now saw " 'home' in the larger sense of Country and of Empire". ${ }^{68}$ There was, however, no place for amateurs in time of war; women had to be trained if they were to be taken seriously by men, so she emphasized the need for "serious" training and the formation of an army medical corps for women. ${ }^{69}$

Notwithstanding the ideological differences, and the SWH's tendency to play down its suffrage origins, there are similarities between the three organizations. Unlike the other

\footnotetext{
${ }^{66}$ Letter to Millicent Garrett Fawcett from Elsie Inglis, 9 Oct. 1914. Women's Library, 7/MGF/94. Red, white and green were the NUWSS colours.

${ }^{67}$ Leah Leneman, In the service of life: the story of Elsie Inglis and the Scottish Women's Hospitals, Edinburgh, Mercat Press, 1994, p. 110.
} 


\section{Jennian F Geddes}

wartime voluntary hospitals founded by women, none of them appear to have been started primarily for patriotic purposes. Patriotism may well have been a factor, but their founders' overriding concerns seem to have been focused on a woman's right to participate fully in the war, in the face of considerable official opposition. The extent to which they aired these convictions or spelled out the implications of women's participation varied. Arguably the most successful of the three in achieving public acceptance was the Women's Hospital Corps, which made no secret of its feminist philosophy. All three had political agendas, but because the WHC was working in an official hospital away from the fighting it had opportunities, not available to the others, to incorporate the suffrage campaign into its operations, and was able to elaborate a distinctive feminist ethos.

It was not just a question of proving they could do a man's job in a man's world; the WHC wanted to do the job better than men, which meant doing it differently. This they achieved by capitalizing on the fact that they were a women-run institution. I have described how they took advantage of their anomalous situation in the RAMC to deviate from normal army practice, using traditional feminine skills to subvert military tradition in small ways in order to humanize their hospital and improve their patients' psychological welfare. It appears that the women felt sufficiently confident about their abilities not to ape the traditional military hospital, but to develop a feminism centred round the fact that women are different. Having successfully taken on the heroic male role of army surgeons, they had achieved equality with men, but realized they could achieve still more by recognizing (and fulfilling) maternal obligations towards their patients. ${ }^{70}$ An anonymous commentator in the Tatler acknowledged this, praising "the noble ladies who manage the Suffragette hospital in Endell Street. They are men in the best sense of that word, and yet women in the best sense of that word also". ${ }^{71}$ Murray and Anderson's success was primarily in exploiting the fact that they were women treating men.

There is no doubt that the First World War produced extraordinary gender reversals, probably nowhere more evident than in women's military hospitals. Endell Street, situated in the centre of London, not in far-flung Salonika, provided daily proof of this. Men newly arrived from the trenches found themselves under the command of women and totally dependent upon them for their survival; once the surgeons had amputated their limbs, set their fractures and dressed their wounds, their convalescence was to be spent in the most womanly of pursuits, sewing (in one case, embroidering a portrait of one of the Commanding Officers), ${ }^{72}$ and producing items for hospital sales of work. As we have seen, all this was minutely chronicled in the newspapers and magazines of the day. The evidence though is that the wounded men accepted this upset in gender roles unquestioningly, relishing the contrast between the therapeutic ambiance of the hospital and what they had been through at the Front. Not an entirely disinterested witness, Murray says of the men that they "were wont to develop amazing confidence in the ward doctors and to discuss the merits of the various surgeons in the square. Each man thought his ward the best ward in the hospital, and his doctor the best doctor on the staff", ${ }^{73}$ however, supportive evidence comes in an extract from a soldier's letter from France, published in the national press and reproduced

\footnotetext{
${ }^{70}$ See Anderson's 'Large babies' speech, cited note 37 above.

${ }^{71}$ WLLGAP, 7LGA/3, cutting in Murray's scrapbook, 19 July 1916.
} 


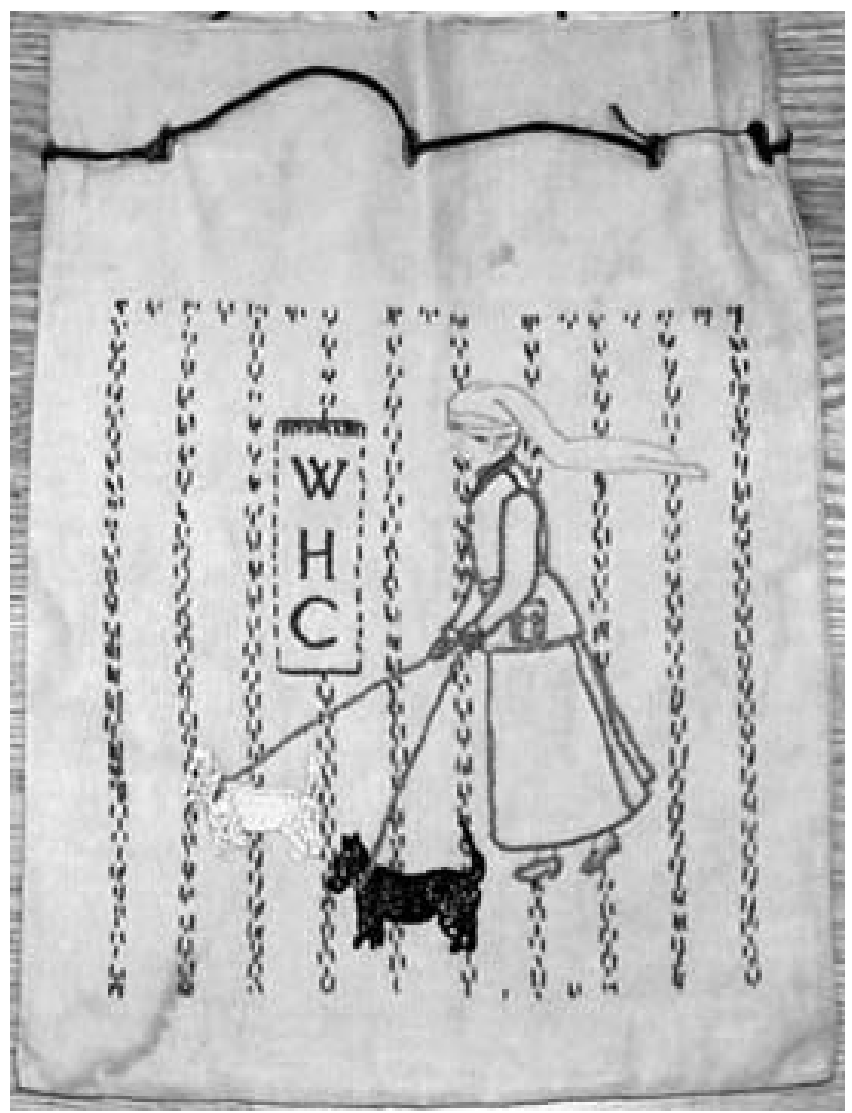

Figure 3: A shoe bag, embroidered by a soldier at Endell Street, shows one of the Commanding Officers walking her dogs (courtesy of the Anderson family; object now in the Women's Library).

by the LSMW school magazine: "I got hit by a shell bursting over our trench-in the face, neck and shoulder. I am in one of the very best of hospitals - a ladies' hospital. Lady doctors do all the work-no men at all, so you can guess I am all right" ${ }^{74}$ A wounded Australian soldier treated at Endell Street wrote home to his father: "the Women's Hospital Corps hospital is the best in London. The management is good, and the surgeons take great interest in and pains with their patients... The whole hospital is a triumph for woman, and incidentally it is a triumph for suffragettes." 75

According to Murray, only one man asked to be transferred from Endell Street when he arrived, on the grounds that he did not want to be treated by women, but he rapidly changed his mind and "sent his mother to ask that he might remain". Even more gratifyingly for the WHC, when a patient was given the opportunity of being transferred to another hospital,

${ }^{74}$ Magazine of the London (Royal Free Hospital) School of Medicine for Women, Mar. 1915, 10 (60): 12. The letter was written at the beginning of January 1915, and, though the hospital is not named, it must have been either the WHC's hospital at Wimereux or the SWH's Abbaye de Royaumont.

${ }^{75}$ The Sydney Daily Telegraph, 19 Nov. 1915, in the Endell Street scrapbook (WLLGAP, 7LGA/3, p. 1). 


\section{Jennian F Geddes}

the offer was invariably turned down. ${ }^{76}$ The trusting acceptance of the situation by soldiers newly arrived at Endell Street contrasts remarkably with the considerable battles that Murray and Anderson found themselves fighting with RAMC officers in the early days of the hospital.

\section{Postscript and Conclusion}

During the war many commentators had confidently predicted radical changes in the status and prospects of women doctors as a result of their war work, Endell Street Military Hospital and the Scottish Women's Hospitals being the most oft-quoted examples. In point of fact, however, very little changed after the war. Medical women were rapidly to discover that society had very few expectations of them, and that largely because of obstructionism within the medical profession itself their post-war career prospects were no better than they had been in $1914 .^{77}$ A glance at the subsequent careers of the highly motivated and experienced women who served in the WHC shows how little their efforts seem to have achieved, in terms of improving the prospects for women in medicine: while four or five became distinguished in their field, the route for the rest was an appointment at a women's hospital, work in the Colonies, or marriage followed by retirement. Where they did remain in medicine they ended up in the same fields in which they had always practised: none of the 37 doctors who served at Endell Street went into general surgery or medicine, the areas in which many of them had the greatest expertise. ${ }^{78}$

The intransigence of the medical profession as a whole meant that the only significant consequence of medical women's often heroic wartime service was the breaking of the taboo on women being doctors for men ${ }^{79}$ — undoubtedly helped by the opening of male medical schools to women during wartime. Permission to treat male patients might seem a relatively poor return for five years of dedicated war service by women doctors, and in one sense it undoubtedly was. However, there was one other less obvious gain. Both the WHC and the SWH had received a huge amount of favourable publicity throughout the war, and there is no doubt that largely as a result of this public interest women doctors came out in 1918 with their image immeasurably enhanced. They had shown themselves to be administratively and professionally capable of running hospitals, of coping with complex medical and surgical problems and of competently treating wounded soldiers under stressful wartime conditions, often suffering considerable hardship and privations in the process. Endell Street had cared for over 26,000 patients, and Royaumont nearly 11,000, the vast majority men, without social and moral collapse. ${ }^{80}$ It was no longer inappropriate for women to practise military medicine, though it would be some time before that fact would be officially acknowledged. ${ }^{81}$

\footnotetext{
${ }^{76}$ Murray, op. cit., note 1 above, p. 147.

${ }^{77}$ Mary Anne Elston, 'Women doctors in the British Health Service. A sociological study of their careers and opportunities', PhD thesis, University of Leeds, 1986, pp. 303, 352.

${ }^{78}$ Geddes, "Women as army surgeons", , op. cit., note 1 above, pp. $80-1$.

${ }^{79}$ Elston, op. cit., note 77 above, p. 295.

${ }^{80}$ The figure of 26,000 patients given by Murray and others includes 2,000 women, mostly WAACs, but does not include a very large number of outpatients, in
}

the region of another 20,000, also mostly male. The largest SWH hospital, Royaumont treated 10,861 patients, of whom 8,752 were soldiers (Crofton, op. cit., note 31 above, p. 225).

${ }^{81}$ When the Second World War started, women doctors encountered many of the same prejudices and barriers: Albertine Winner, 'Medical women in the forces. Part iii: Women doctors in the armed forces in the Second World War', J. med. Women's Federation, 1967, 49: 103-7. 